\title{
"This is proof"? Forensic evidence and ambiguous material culture at Treblinka extermination camp
}

\author{
Caroline Sturdy Colls $^{1}$ and Michael Branthwaite ${ }^{2}$
}

\begin{abstract}
In recent years, a forensic archaeological project at Treblinka extermination camp has uncovered significance evidence relating to the mass murder that took place there. A number of questions emerged regarding the provenance and origins of objects discovered as part of this work, and why they had remained undiscovered for over seventy years. These discoveries led to an opportunity to confirm and challenge the history of the extermination camp, and demands (from the public) to view the objects. This paper will outline how archaeologists and artists came together to reflect on these issues, whilst simultaneously providing access to the new findings.
\end{abstract}

KEYWORDS: Holocaust archaeology; Treblinka (extermination and labour camps); forensic archaeology; non-invasive research; artistic responses; contemporary art practice.

\section{INTRODUCTION}

The persecution and mass murder of between 800,000 and 1,000,000 people at the Nazi German extermination camp in Treblinka (Poland) remains one of the most abhorrent and voluminous crimes of the twentieth century (Figure 1). Between the 23 July 1942 and September 1943, the camp played a central role in the Nazis' attempt to wipe out the entire Jewish population of Europe, hence the majority of victims were Jewish. Roma, Sinti and socalled Polish political prisoners were also killed (Webb and Chocholatý 2014; Arad 1999). Gas chambers were constructed at Treblinka in order to facilitate "efficient" killing operations and the bodies of those killed were buried in mass graves or burnt on cremation pyres. At almost every stage - including deportation to the camp, unloading at the railway platform and transportation to the gas chambers - the Nazis attempted to deceive their victims and to hide the traces of the crimes they committed (Sturdy Colls 2014). A labour camp, which housed Polish political prisoners and Jews with specialist trade skills, also existed at Treblinka from 1941-1944. Very little has been written about the history of this camp, even though approximately 10,000 people died there (Kopówka and Rytel-Andrianik 2011).

When, in the immediate aftermath of the Holocaust, forensic investigators examined the area of Treblinka extermination camp, they suggested that almost all traces of the camp and physical evidence associated with it had been destroyed (for an overview, see Sturdy Colls

\footnotetext{
${ }^{1}$ Associate Professor of Forensic Archaeology and Genocide Investigation, Centre of Archaeology/Forensic and Crime Science, Staffordshire University, Leek Road, Stoke-on-Trent. Staffordshire, ST4 2DF, United Kingdom, c.sturdy-colls@staffs.ac.uk

${ }^{2}$ Senior Lecturer in Fine Art, Art and Creative Technologies, Staffordshire University, College Road, Stoke-onTrent, Staffordshire, ST4 2DE, m.branthwaite@staffs.ac.uk
} 
2014). In the years since, material culture has not featured in historical narratives and so it has only been possible to realise a partial account concerning how the camp operated, what it looked like and what those who encountered it experienced.

Therefore, in 2007 a forensic archaeological investigation was launched to locate, record and interpret any surviving physical evidence at Treblinka in association with other information derived from archives, witness testimonies and modern digital data. Non-invasive surveys, using a wide range of techniques, were undertaken in 2010 and 2012 at the extermination and labour camps respectively. Following this, in 2013, a further survey and excavation at the extermination camp uncovered jewellery, hair clips, tools, pots, pans and other domestic items, thus confirming that mass murder on such a scale had left behind a considerable body of evidence (Sturdy Colls 2015a and b; 2014 and 2012).

A number of questions emerged regarding the provenance and origins of the items, and why they remained undiscovered for over seventy years. These discoveries led to an opportunity to confirm and challenge the history of the extermination camp, and demands (from the public) to view the objects. This paper will outline how archaeologists and artists came together to reflect on these issues, whilst simultaneously providing access to the new findings of all of the fieldwork seasons. It will consider the narratives that have developed around Treblinka's material culture - both prior to and following archaeological research - and the factors that have contributed to this. The ways in which the newly discovered objects and data have led to new knowledge about the events that occurred at the camp will be discussed, as will the reasons why it is necessary to reflect on the ambiguity of forensic evidence and material culture in the context of the Holocaust. The importance of, and motivations behind, exhibiting the findings of archaeological investigations at Holocaust sites will also be addressed. Crucially, this paper will demonstrate how interdisciplinary work concerning material culture can present opportunities for dialogues that provoke change in the way we think about history and its relationship with the present.

\section{[Fig. 1 near here]}

\section{TREBLINKA EXTERMINATION CAMP}

Despite only operating for thirteen months, the atrocities perpetrated in Treblinka extermination camp accounted for a death toll of 800,000 to one million people. The sole purpose of the camp was mass killing and, as such, it had no accommodation barracks for inmates, except those that were used to house a few Jews who were forced to dispose of the victims' corpses. The majority of people sent there were killed within half an hour or less of

their arrival. First they had their personal belongings taken and they were made to walk naked to the gas chambers (Willenberg 1989; Rajzman 1947). Many also died in the trains during the deportation to the camp (Weinstein 2002). The majority of victims were killed in the gas chambers and more and more people were killed over time as the Nazis attempted to perfect their methods of extermination. Initially, three gas chambers operated within one building (known later as the old gas chambers) and then a further ten chambers were built (known as the new gas chambers) in August 1942 (Chrostowski 2004). The latter occurred during a temporary suspension of operations when the new Commandant Franz Stangl attempted to improve the efficiency of the camp and remove the bodies of the victims that lay strewn across the camp area. The bodies of the victims killed in the gas chambers were initially buried in mass graves located in the death camp area, some of which were exhumed later when cremation of the corpses became the main method of body disposal (Sturdy Colls 2014; Donat 1979). Throughout the camp's period of operation, those who could not walk to the gas chambers or 
those who were deemed to be insubordinate were taken to the Lazarett (a fake hospital) in the reception area, where they were executed and pushed into an ever-burning pit (Willenberg 1989). Like the fake railway station, signs and information that existed in the reception area, this hospital structure was intended to maintain the illusion that people who were sent to Treblinka were at a transit camp from which they would be sent 'to the east' (Polish Jewish Magazine, 1.2.7.2/82170514, ITS Digital Archive, USHMM). Although many people initially believed this, most knew that Treblinka meant 'no more life' (Friedman 1996). In the northern part of the camp, the SS and Ukrainian guards had a complex of accommodation barracks, leisure facilities and administrative buildings in which they lived and worked.

The extermination camp was liquidated before the end of World War II. The final transports arrived at the extermination camp in autumn 1943 but operations had already been downscaled earlier following a revolt by the prisoners on the 2 August. The revolt saw around 200 of the men that worked in the camp (sorting victims' belongings, removing the corpses from the gas chambers, burying and burning the bodies etc.) escape, although only around 70 of them reportedly survived the war (Chrostowski 2004). The revolt also resulted in damage to many of the camp buildings, including the gas chambers which, along with the other camp buildings and infrastructure, were demolished completely from mid-August until November 1943 in order to hide all traces of the crimes (1.2.7.7/82183916, ITS Digital Archive, USHMM). A farmhouse was constructed at the site of the camp bakery and dairy, and a Ukrainian guard posted there in order to act as a deterrent and hide the true purpose of the camp (Sereny 1995). When investigators arrived at the site in 1944 and 1945, although they did come across objects, remains of buildings and human remains, these sporadic and damaged remnants were dismissed and their final conclusions suggested that the Nazis had destroyed the traces of the camp and the people sent there (Sturdy Colls 2014; Łukaszkiewicz 1948).

Therefore, despite the physical presence and impact that Treblinka extermination camp had, it has come to be defined by absence. The documented history of Nazis activities - in terms of the confiscation and transportation of belongings, attempts to hide the bodies of their victims and the demolition of the camp - coupled with the lack of emphasis placed on physical evidence by post-war investigators, has contributed to the notion that material culture relating to the camp did not survive. At the time of the archaeological investigations at Treblinka (20102013), the terrain of the former extermination and labour camps housed the Museum of Struggle and Martyrdom in Treblinka, which included a small permanent exhibition and a memorial landscape (constructed in the 1960s) (Figure 1). Only a few information panels existed to indicate to visitors what the camps would have looked like (as far as was known) and the popular narrative of the site was one that stressed that the site had been destroyed. Only a handful of objects, mostly from the labour camp, featured in the museum exhibition at Treblinka, whilst only a very small number of others exist in archives around the world. Hence, discussions concerning materiality at Treblinka were virtually non-existent just as, or so it seemed, was materiality itself.

\section{ARCHAEOLOGICAL APPROACHES TO TREBLINKA EXTERMINATION CAMP}

Could it really be possible that this small amount of material culture was all that survived of one of the largest killing sites in world history? This seemed unlikely and, having reviewed the original reports of post-war investigators, in which they observed a considerable amount of material that archaeologists would deem highly important today, clear evidence was provided that supported this theory (Sturdy Colls 2014). Therefore, the Finding Treblinka project was initiated with the aim of using modern forensic and archaeological techniques to create a more accurate record of both the extermination and labour camps, and the processes 
of extermination and internment connected to them. By drawing on a range of innovative technologies and techniques, the research attempted to identify what physical evidence survived in situ and enrich the history of the site based on new information derived from these material traces.

\subsection{An Interdisciplinary Approach}

The archaeological investigations at Treblinka drew upon a wide range of interdisciplinary methods to account for the diverse nature of the terrain and potential material culture across both camps. Narratives concerning Treblinka to date have relied almost exclusively on documentary evidence. Whilst this material has considerable value, this approach has caused other evidence types to be overlooked. A broad range of complementary historical and scientific methods now exist that can assist in the examination of these various types of evidence, thus allowing a much richer account of the crimes perpetrated at Holocaust sites to emerge. Detailed archival research was conducted - drawing upon a wide range of documentary, photographic, aerial reconnaissance and cartographic sources - and oral testimonies were collected. However, as well as more traditional forms of enquiry, analysis of them focused on extracting information about the materiality of the camps and understanding post-war approaches. A range of non-invasive methods were then utilised to record the topography of the site and surviving above-ground evidence (e.g. walkover survey, LiDAR, Differential Kinematic GPS, Total Station survey, 360 degree photography), and to record buried remains (e.g. using geophysical survey in the form of Ground Penetrating Radar and resistance survey). Finally, targeted excavations were carried out in 2013 to confirm the presence of mass graves at the execution site close to the labour camp and to identify the function of some of the structures observed in the geophysical survey data from the extermination camp. The latter specifically focused on the area where the gas chambers were thought to be located. A $1 \mathrm{~m} \times 1 \mathrm{~m}$ trench (Trench 4) was excavated in the centre of a $22 \mathrm{~m} \mathrm{x}$ $15 \mathrm{~m}$ anomaly recorded by the GPR survey, which appeared consistent with a building foundation. A further trench (Trench 3), measuring $2 \mathrm{~m} \mathrm{x} \mathrm{1m,} \mathrm{was} \mathrm{excavated} \mathrm{to} \mathrm{the} \mathrm{west} \mathrm{of} \mathrm{this}$ area in an area of scattered debris identified in the GPR results. For further information about the techniques mentioned here, the reader is referred to Sturdy Colls (2015).

\subsection{Finding Treblinka}

The archaeological investigations at Treblinka yielded a considerable amount of buried and surface evidence, demonstrating that material traces relating to the camps had not been found because they had been overlooked, not because they did not exist. Many of these findings have been described elsewhere and therefore, given the limitations of space and the focus of this article, the reader is referred to these sources for further information concerning the layout of the sites and the structures located within them (Sturdy Colls 2015a and b; 2014; 2012; and 2015c; Sturdy Colls and Branthwaite 2016). Owing to the wealth of material culture that was found within trenches 3 and 4, and the role that they played in the dissemination programme that was to follow, this paper will focus predominantly on these areas. The excavation of trench 4 confirmed that the $22 \times 15 \mathrm{~m}$ anomaly in the GPR results did in fact represent the foundations of the first gas chambers built by the Nazis at Treblinka (known as the old gas chambers), which existed at a depth of $0.85 \mathrm{~m}$ below the ground. 712 individual items were also recovered from this small trench. These items can be divided into three groups:

(1) Building materials - e.g. tiles, bricks and plaster

(2) Personal belongings - e.g. jewellery, hair clips, a belt buckle and coins 
(3) Functional items - scissors, a knife, bullets, a battery, glass etc.

A selection of the items found are shown in Figure 2.

Dentures, and gold and silver teeth were also found along with a considerable amount of fragmented human remains, some of which exhibited evidence of burning and some that did not. All of these different types of material traces were commingled, confirming the nature of destruction afforded to the gas chambers in autumn 1943 and the heavily disturbed nature of the ground exhibited in the GPR results. This was further established by the discovery of 286 objects in trench 3 , which existed outside of the area of the gas chamber foundations. The items found in this area can also be grouped into the categories outlined above and human remains were also found intermingled with the objects in this area.

Additionally, a further 79 objects were found on the surface during the walkover survey in an area known to have contained the camp's waste pit. The majority of these items were domestic in nature. A pan, bowls, cups, beer bottle tops and cutlery were all recovered, as was a metal sign bearing a swastika and the words "Lager Polizei" (Camp Police) (Figure 3).

Following the discovery of these items, it was the ambition of the project team to identify what they could reveal about individual and collective experiences in the camp, and to explore the reasons why they had previously been overlooked. These findings are discussed further in Section 5 below.

[Fig. 2 near here]

[Fig. 3 near here]

\section{ARTISTIC RESPONSES}

Following these new discoveries, it was necessary to revisit and revise the accepted narrative of Treblinka and to disseminate this new information as widely as possible, in order to provide new opportunities for commemoration and education. However, as observed above, material culture had not previously played a notable role in narratives or heritage presentation at or about Treblinka. Therefore, introducing this newly discovered material into these narratives and ensuring that its value was recognised amongst scholars and the public alike was considered a major challenge. Likewise, because the excavations at Treblinka formed a small part of a larger non-invasive approach, much of the remaining data collected during the archaeological research was highly specialized - e.g. geophysical and topographic survey results - and therefore was difficult for non-specialists to understand. Any dissemination strategy needed to provide public access to these complex findings in an effective and innovative way. Additionally, as already discussed in Sturdy Colls (2015b), any attempt to disseminate the findings of the archaeological research at Treblinka had to consider that, on the one hand, people from a diverse range of religious, cultural and social backgrounds visit Treblinka, many of whom want to learn more about its history and, on the other, many people across the world are unable to visit the site at all.

\subsection{Developing the Artworks}

In order to address these challenges and to ensure that a successful dissemination strategy was developed, archaeologist (Caroline Sturdy Colls) and artist (Michael Branthwaite) formed a collaboration. During this next stage of the Finding Treblinka project, the authors aimed to explore how archaeology and art could enhance public knowledge about sensitive and 
traumatic events, and raise awareness of the historically important, but barely known, crimes perpetrated within the camps via the material culture relating to them.

This was achieved via two initiatives: (1) the development of a factual exhibition centred on the newly discovered remains at Treblinka and (2) the commissioning of artworks that responded to the archaeological findings. The former centred first on a permanent exhibition at the Museum of Struggle and Martyrdom at Treblinka in Poland, which aimed to provide visitors with a new history of the crimes perpetrated in both camps (Figure 4). The exhibition follows the journey and experiences of people who encountered the camps and tells their stories through a combination of objects, information panels, quotations from witnesses, maps, drawings and aerial images. Of particular note are eight specially selected objects that highlight both individual and collective experiences within the camp - these include the tiles from the gas chambers, individual items of jewellery found in the extermination camp and shoes found in mass graves at the labour camp. The central part of the installation is a $1 \mathrm{~m} \mathrm{x} 1 \mathrm{~m}$ purpose-built cube that symbolises the excavated area in the centre of the gas chambers at Treblinka where thousands of fragments and objects were found.

In conjunction, artworks were commissioned in order to provide alternative forms of access to the archaeological findings and to explore some of the philosophical questions posed by the discovery of certain objects. To initiate this process, a visit to artists' studios was undertaken by the authors. Artists were shortlisted following this visit, based on their credentials and initial ideas about the project, and they were then invited to a semi-formal meeting. During this meeting, Dr Caroline Sturdy Colls shared a series of 30 images with the artists, which included photographs of the objects found during excavations at Treblinka, digital geophysical and topographic survey data, photographs of meetings with survivors, lists of materials found, maps, plans and aerial photographs. Stories concerning the fieldwork and experiences of meeting survivors were also shared. The artists were then asked to prepare an application to participate, outlining their proposed artwork (with images), a narrative about why they hoped to participate and a professional bio. A lead artist (Michael Branthwaite) and four selected artists were chosen and they received commissioning instructions and set about making their artworks. Each artist followed a personalized methodology that allowed them to explore the Interactions between information, idea and aesthetics.

\section{[Fig. 4 near here]}

\subsection{The Responses}

The result was a diverse range of artworks that fore-fronted the material culture relating to the camps (Sturdy Colls and Branthwaite 2016; Figure 5). Janine Goldsworthy's work 'Rose Brooch' took a very personal item - a rose-shaped brooch found close to the gas chambers and laser cut an abstraction of the object outline through a thin piece of fragile paper. This was then presented on a plinth with a projected video of a YouTube clip about Treblinka, thus linking online representations of the site with documented evidence found at the site. Jenny Steele was touched emotionally by the personal items and decided to act on this by creating a print of hair clips found at Treblinka that was then used to refurbish a period chair, combining the shocking with the mundane and the personal as a reaction to the alleged use of hair in furniture assembly. Hilary Jack reacted the large amounts of items unearthed in the trench 4 during the 2013 excavations at the site by taking a sample of the discovered items and overloading a $1 \mathrm{~m} \times 1 \mathrm{~m}$ acrylic sheet with vinyl text of the litany of objects. Dave Griffiths responded to the process of finding, unearthing and documenting the items by creating a microfilm archive of the findings. The viewer then needed to navigate to find (or re-find) the data and articles collected, echoing the archaeological process. Finally, Michael Branthwaite 
displayed a pan found during an archaeological walkover survey at Treblinka in 2013 in a frosted acrylic display case on a museum style plinth. Four conflicting interpretations relating to the pan (derived from archaeologists and witnesses) were attached on each face of the plinth, presenting the viewer with the reality that historical narratives are sometimes paradoxical and inconclusive. These items were included in a temporary exhibition, entitled "Finding Treblinka: Artists Respond", on the first floor of the Museum of Struggle and Martyrdom in Treblinka.

Whilst the initial focus of the project was this permanent exhibition, central to this was the exploration of Treblinka as a moving entity that exists in a world governed by politics and wider Holocaust histories related to it. In the long-term, the exhibition itself would also become a moving entity as a travelling version was planned in order to provide access to those unable to visit the site. This culminated in an exhibition at The Wiener Library in central London in July 2016 (Figure 6). As the objects remained in Treblinka, this exhibition used a combination of information panels, digital media, artworks and items from the Wiener Library's collections to shed new light on the crimes perpetrated at Treblinka. Like the permanent exhibition, this exhibition also focused on the experiences of those held in both camps at Treblinka and outlined the forensic archaeological processes that led to the discovery of this evidence. It was the authors' intention in this exhibition to integrate the artworks into the main exhibition for two key reasons. Firstly, in the absence of the actual objects, the artworks retained the emphasis on materiality that was present in the original exhibition, since each included a motif or reference to an item/items found at the site. Secondly, the artworks responded to and provoked both some of the questions the archaeologists posed after discovering the material and that the artists generated whilst creating their works. By focusing on the works and these questions, viewers of the travelling exhibition had the chance to explore ways in which archaeological data and findings could be processed. This "problematisation" of the findings through artistic interpretations and responses was intended to offer a "lens" through which to perceive them and connect them to wider contextual concerns and discourses.

[Fig. 5 near here]

[Fig. 6 near here]

\section{CONFIRMING AND CHALLENGING HISTORY}

The discovery of material culture at Treblinka permits a review of its accepted history. However, it is important to note that this was only possible by considering the objects in conjunction with the results of the non-invasive surveys and new historical research concerning the site. Firstly, the discovery of objects, foundations of structures, the camp boundaries and a wide range of other traces of the camp's existence, clearly demonstrates that the site was not devoid of evidence as some post-war sources suggest.

The discovery of the tiles and building materials during the archaeological excavations (Figure 2), confirmed the location of the old gas chambers and the testimonies of witnesses that stated that the floor was covered with red/terracotta tiles (for examples, see Krzepicki 1979 and Wiernik 1944). Secondly, the fact that these tiles have been observed in a number of Jewish ritual baths (mikveh) gives cause for further investigation into whether or not they were specifically chosen so that the Nazis could make the gas chambers appear not only as a bathhouse, but as a Jewish bathhouse (Sturdy Colls 2015). Research is ongoing in this regard.

In contrast, the discovery of personal belongings in the gas chamber area appears to challenge the accepted history of the site, which states that people were stripped on these items 
when they arrived at the camp. Upon discovering these items, further archival research was undertaken which did in fact reveal testimonies that stated that people were sometimes sent clothed into the gas chambers when the camp was operating to full capacity. In fact, a testimony written by Rudolf Höß, the camp commandant of Auschwitz-Birkenau, stated that this was common practice when he visited the camp in 1943 (Notes of the former camp commander Rudolf Höß, 1.1.2.0/82344521, ITS Digital Archive, USHMM). Likewise, although women sometimes had their hair cut prior to entering the gas chambers, witnesses allude to the fact that haircutting sometimes took place within the gas chamber building, prior to gassing, or even after people were killed (Rajchman 2011; Bomba 1996). This offers a viable explanation as to why large numbers of hair clips and combs were found in the rubble directly above and adjacent to the gas chambers' foundations (Figure 2).

Popular histories about Treblinka commonly refer to the fact that all of the victims were cremated, owing to the presence of cremation pyres at the site from November 1942 and witness testimonies that observe that bodies originally buried in mass graves were also dug up and burnt in February 1943 (e.g. Chrostowski 2004; Arad 1999). However, the discovery of unburnt and partially burnt human remains during the excavations seems to suggest that this was not a universal practice. This is confirmed by lesser-known testimonies, which again suggest a more chaotic system when large numbers of people were being transported to the camp (Sturdy Colls 2015a).

The archaeological excavations, and prior to that geophysical surveys, also offered the possibility to make important observations concerning the reasons why post-war investigators were dismissive of the material traces they came across. In the short time they spent at the site, they only undertook limited excavations and, as such, they failed to locate features such as the foundations of the gas chambers, which were buried under a considerable amount of sand and rubble. Secondly, the heavily disturbed ground, which contained a mixed array of objects, rubble and human remains likely appeared to be nothing more than demolition rubble mixed with the surviving remnants of the last days of the camp's period of operation. In the absence of archaeological input in these investigations, it is possible to see why this might have been the view of the investigators. The failure to find these items until more than seventy years after the crimes were perpetrated certainly demonstrates that the Nazis were, for a long time, successful in hiding the evidence of mass murder. It also reveals the shift that has occurred in terms of the perceived value of objects - especially fragmented, scattered and mundane items - within forensic and archaeological circles in the years since the war. What post-war investigators considered to be merely waste, are now seen (in the case of some items) as vital evidence of the Nazis' crimes and the victims' experiences.

\section{BUILDING NARRATIVES AROUND OBJECTS}

Building narratives around objects, particularly those found decades after historic crimes took place, is not without its problems. Likewise, the challenges involved in representing the Holocaust in exhibitions have been well documented by scholars from a variety of disciplines. As the Finding Treblinka project endeavoured to engage in both activities, we were forced to address these issues on both fronts. The following discussion of our approaches and these challenges intends to provide examples and inspire dialogue with others working in this or similar fields, and highlight solutions that were derived through the collaboration of archaeologists and artists.

\subsection{Exhibiting Objects in the Finding Treblinka Exhibition}

Objects present in exhibitions often have to fulfil a complex range of roles. Traditionally, this has been one of 'documentation, information and fascination' in museums connected to World 
War II (Kjedbaek 2009). 'Fascination' at Holocaust sites and museums has been the source of much debate in the context of wider discussions concerning dark tourism (for examples see Partee Aller 2013; Young 2009; Stone 2006; Linenthal 2001; Lennon and Foley 2000) and curators must find a balance between engaging visitors and opening up possibilities 'without feeding people's propensity to glorify war, stoking their macabre or voyeuristic fascination with terror, trivializing the event, and, above all, sacrificing the victim's dignity - essentially making them victims for a second time' (Ehrenreich and Klinger 2014: 113). When developing the Holocaust exhibition at the Imperial War Museum, Taylor (2014: 151) notes that contemporary items 'would not only have to tell a story, but also to act as evidence of a crime that the perpetrators had made strenuous efforts to conceal'. At sites where crimes occurred, curators have stated that 'one assumption is that exhibitions cannot be more important than the camp area, and cannot obscure or dominate it by means of modern technology; on the contrary, they have to perform an ancillary role: they are meant only to help visitors read the history of the camp' (Ziębińska-Witek 2014: 267-268). But how true is this in relation to Holocaust sites? Whilst undoubtedly the railway tracks, the crematoria and the 'Arbeit macht frei' signs at Auschwitz-Birkenau are iconic symbols of the Holocaust, the shoes, suitcases, hair and personal belongings within the museum surely offer visitors more than just a narration of these sites? As Dalton (2009: 218) argues, 'the very relics and remnants of Auschwitz-Birkenau provide a powerful backdrop — a type of mise-en-scene — that helps animate the imagination... and...invoke a powerful affective sense of individual loss'. At many Holocaust sites, these items are often the only visible traces that the people who suffered at the hands of the Nazis left behind (as opposed to the structures which were designed and operated by the perpetrators) and, therefore 'displaying personal items in context can turn the huge numbers of victims back into individuals and return their humanity' (Ehrenreich and Klinger 2014: 146). For many survivors and descendants, these items provide a connection to loved ones and ancestors who were killed, and they can also be used to educate future generations about the crimes.

At sites like Treblinka, where no in situ remains exist and where it is difficult for visitors to understand what happened because of this absence, the role of the objects found during archaeological research certainly do have to 'help visitors read the history of the camp' but they also assume an importance that elevates them beyond this remit (Ziębińska-Witek 2014: 267268). Here, the items found during archaeological excavations, along with a handful of items found on the surface of both camps in the decades since the war, represent the only visible traces that visitors could potentially see. Hence, their rarity combined with the absence of above-ground material traces bestows a unique educational value upon them and offers the potential to provide new information to visitors about the events and experiences pertaining to the camps.

At Treblinka, effectively exhibiting these items, without either embellishing their importance or overshadowing it, represented a challenge that other curators at Holocaust sites will undoubtedly relate to. As Ziębińska-Witek (2014:269) has suggested, 'sensory shock' has been employed as a technique in exhibitions in the past, whereby brutal images, large amounts of deplorable images and thousands of personal objects have been displayed as a means of causing visitors to experience physical disgust concerning the crimes perpetrated. As Young (2009: 59) argues of Auschwitz-Birkenau, 'showing the items en masse can be effective in prompting visitors to contemplate the scale of Auschwitz's operations, but in this way it also distances visitors from the experiences of the individual prisoners'. Therefore, just as the design team that created the United States Holocaust Memorial Museum expressed 'concern that the millions of individual deaths that made up the Holocaust would be lost in a story of mass death and overwhelmed by a fascination with the techniques of mass destruction', so too the authors felt that innovative ways needed to be found to prevent a situation whereby visitors were so 
overwhelmed by the scale of the atrocities at Treblinka that they were unable to comprehend them (Linethal 2001: 171). Avoiding a situation whereby the crimes are either sensationalised or censored is a challenge experienced by anyone engaged in the representation of material culture (or at least anyone conscious of this problem who does not seek to deliberately present material in such a fashion) (LaCapra 1996).

Within the museum at Treblinka, our approach was to highlight the nature of the atrocities perpetrated via the window provided by the $1 \mathrm{~m} \times 1 \mathrm{~m}$ trench excavated in the centre of the old gas chambers, symbolised by a $1 \mathrm{~m} \times 1 \mathrm{~m}$ display cube (Figure 4). However, we deliberately did not place large amounts of similar material together to show volume, but rather we separated out a representative sample of items in order to make the findings more comprehensible. Had we filled the whole cube with commingled items (which we could easily have done), it would have been difficult for visitors to comprehend their function. Instead, visitors were left with the impression of destruction (because of the condition of the objects), whilst they were also able to identify the form these items took before the gas chambers were destroyed. In doing this, we also aimed to demonstrate the nature of the discoveries that were made in this area using archaeological techniques and to allow people to extrapolate out how much material must exist across the rest of the site if this much existed in a $1 \mathrm{~m} \times 1 \mathrm{~m}$ area. The construction of the gas chambers, the ways in which they functioned and their place in the overall experiences that people sent to the camp had was explained on accompanying information panels, alongside additional information concerning how they were discovered e.g. via non-invasive survey and then excavation. Items found on the surface during walkover surveys of the extermination camp area were also displayed in two larger cabinets, representing the scale and scattered nature of these assemblages when they were found. They too were accompanied by information that explained the origins of the objects (where these could be confirmed) and the challenges of interpreting un-stratified items.

Having alluded to the scale of the atrocities, the placement of individual items in individual display cubes aimed to individualise the experiences of victims. In relation to the extermination camp, a selection of hair clips, scissors, a knife, a tile from the old gas chambers, a rose-shaped brooch and a gold pendant were chosen for these display cases because they illustrated an array of experiences that people had when they travelled to and through the camp, journeys which were described on accompanying information panels. Shoes and bullets found in two mass graves south of the labour camp provided the material evidence to accompany the history of this site. Hence, items were shown that simultaneously represented 'both the life and death of their owners' (Evans 2014: 157). Quotations from camp inmates and witnesses also sought to convey both individual stories and interpretations concerning the function and provenance of the objects. This approach echoed that utilised at Srebrenica in BosniaHerzegovina, where individual items and information about their owners are individually displayed, encouraging (and almost compelling) visitors to encounter each person and learn about the array of experiences during this genocide (Potarcari Memorial 2016). Although the items at Treblinka could not be attributed to individual people, the placement of the items in this way encouraged visitors to reflect on and question who they may have belonged to and what they may have experienced. The anonymity of the objects also reflected the ways in which the Nazis stripped people of their identities via the array of measures they implemented in both camps.

\subsubsection{Art as Narrative}

At both Treblinka museum and the Wiener Library, the artworks also contributed to the narrative of the site and exhibitions, inspired new discussions concerning the themes upon which they focused and enabled us to address many of the challenges outlined above. 


\subsubsection{Addressing Sensitivities}

This was, however, only achieved because we addressed the possible ethical issues that could arise from commissioning and contextualizing the artworks throughout the lifetime of the project. For example, the choice of what to respond to was deliberately left to the individual artists so that both their practice and personal interests could be used to find new ways of creating points of departure for debates. The breadth of the approaches taken is testament to the success of this approach. However, this method may not have been without consequence, as the fact that something could be misinterpreted or produced in an unethical manner was always a possibility. Choosing artists with an established track record and ensuring the nature of the project was made clear (through on-going dialogue with the lead archaeologist) was key to ensuring that the works functioned in a sensitive way, in keeping with the projects aims.

It was also imperative from the start to identify clearly what the purpose of the artworks would be, as a decision was reached that simply exemplifying the horror and scale of the atrocities would not add to any cultural debate and it may be offensive. Additionally, any work focused on this would most likely fail to deliver anything beyond what the existing factual account and cultural memory of the site already offered. Therefore, we decided that interrogating the contemporary situation at the site and focusing on the material traces located during the archaeological investigations would provide the best scope for broadening the avenues for dialogue.

\subsubsection{Using Art to Explain Science}

Although the findings at Treblinka offer those able and willing to interpret complex, scientific data a new and progressive insight into the camps, we could not assume that all visitors would have this capacity. For example, how could we tackle the importance of the LiDAR survey information - which helped confirm the location of the gas chambers and mass graves - in a way that claimed its significance but also made it understandable and accessible to a general audience? Dave Griffiths' artwork, 'Deep Field [Looking Squarely Ahead]', tackles these issues and attempts to allow access to this hard to decipher information by condensing it on a microfilm to produce an interactive artwork. This work encourages the viewer to explore a 'field' of information relating to trench 4 that incorporated archival information alongside LiDAR data and images of the objects. Therefore, it offered the viewer a chance to access the rich textures of the findings whilst performing the role of finding, and giving meaning to data and information - much like an archaeologist.

\subsubsection{Adapting Narratives}

Regarding the exhibitions as a whole: laying out what has been achieved, at the museum at Treblinka, we have curated two spatially separate but thematically connected exhibitions; an art exhibition and an archaeological exhibition (Figure 4 and 5). At the Wiener library we have combined both archaeological findings and artistic responses into one whole transdisciplinary exhibition (Figure 6). These approaches responded specifically to the particular nature of the differing policies of our two exhibition spaces. At the Treblinka museum for example, we were unable to combine both factual and interpretive information in one whole exhibition as we originally intended. With one large exhibition room that housed the permanent collection and a multi-use exhibition/ conference room on different floors, we needed to curate the shows so that there were visual connections as well as subjective materials to encounter. As we were designing the exhibition from scratch to include all the display cases and plinths, we had the 
opportunity to select and work with artists whose practice engaged with the museum aesthetics, allowing a visitor the opportunity to build links between the objects and data presented in the archaeological exhibition and the artworks in the art exhibition. At the Wiener Library, we had the opportunity to work to our original project design, which presented the archaeological findings and artworks in dialogue with each other through the questions and themes they each invoked (Figure 6). As the original objects remained in Poland, the artworks also gave them a presence in the exhibition, thus keeping the focus on material evidence.

\subsubsection{The Role of Art}

But to what extent do the narratives of material culture presented offer the artist and the audience a means to further their thinking, to re-imagine the site maybe not as it was, but as it is and is becoming? As Schapp et al (2004: 13) states, 'it is not only that archaeologists gather fragments and build collections. Like memory, the work of archaeology is re-collection-the reinsertion of pieces of the past into a form that carries significance in the present, carried forward from the past'.

If we take this as read and apply it to the exhibitions at Treblinka then in effect the artworks are offering ways in which what has been found can be 'carried forward from the past'. As we will discuss now, these possible futures are wide ranging; some offer moral reminders of the past as something to be mindful of in the future, whilst (at the other extreme) some embrace the notion of a fractured reality with multiple meanings and the uncertainty that this might bring in future readings of these findings. Steele's work and the use of combs in the print on the re-upholstered chair (to echo the actual personal items found and displayed as part of the archaeological exhibition) can be read as a memorialisation of an event in a way that subverts the practical function of the chair as an easy to decode object and then encodes it with illustrations of the articles displayed in the cases of the archaeological exhibition; hence, it is a reminder of the past and its place in the present. In contrast, Goldsworthy's intentional blurring of an online survivor testimony using the filter of the rose-shaped brooch discovered at the site posed key questions regarding the role of a museum as a purveyor of the past vs. the role of the digital world, where findings and attitudes are constantly developing amongst online communities. The distortion present in the artwork also spoke to the issue of Holocaust denial and the manipulation of evidence, both of which the archaeologists working at Holocaust sites will likely experience in relation to the remains that they uncover (for examples, see Sturdy Colls 2015a: ch. 11).

The artworks also offered another way to tackle issues of identity and anonymity within the narratives of Treblinka. Artists have used a myriad of strategies throughout the period of modern and post-modern art to explore these issues. The artworks we have made and commissioned fit into this lineage and are reminiscent of works such as Ellen Rothenberg's 'The Combing Shawl' (which uses Anne Frank's combing shawl as a trigger point to explore her individuality and take account of her as a person) and Fabio Mauri's work 'Western of Wailing Wall' (which used old leather suitcases to create a wall, both acting as a barrier and a symbol of 'an' individual and a life lived). These works and our own reflect the known mechanisations used by the Nazis to strip away the identity of their victims and our willingness to create and draw attention to speculative identities was a key feature of our dissemination strategy. In the authors' view, this interdisciplinary project was also a way to explore/provoke discourses that offered a varied and adaptable means to address the atrocities committed at Treblinka in a way that places the audience in a contemporary position, by illustrating the impact of racial hatred through the archaeological findings and artworks. 


\subsection{Ambiguity and "Many Truths"}

Whilst many of the objects found during the course of archaeological research at Treblinka could be dated to the Holocaust era, the origins of others could not so easily be determined due to the fact that they were un-stratified and/or they did not bear identifiable markings. This raises important questions concerning at what point objects are defined as important and relevant.

Ambiguity within the forensic process has most commonly been viewed as problematic and even damaging in cases that are being tried in Court. However, the historical distance between contemporary investigations at Holocaust sites and the crimes to which they relate, means that dating objects and determining their place within narratives can be extremely difficult. Some archaeologists may well be inclined to omit such materials from discussions concerning sites - relegating them only to a line in a finds database perhaps. Instead, these items should be viewed as an important part of Holocaust historiography, since their multiple interpretations can provoke valuable discussions regarding the value placed upon objects, the development of cultural memory and the implications of a failure to investigate crimes at the point at which they occurred.

Let us consider one example: A metal pan was found during a walkover survey at Treblinka in an area of woodland believed to contain the camp's waste pit (Figure 3, top left). Whilst the pan was of a type that was in use during the World War II, and whilst its proximity to the waste pit area may indicate that it was contemporary with the camp, research by the archaeological team demonstrated that this type of pan is still manufactured today. In the absence of any dating evidence and on the basis that the pan was un-stratified, its provenance could not be determined. Instead, it could only be stated that it was possible that it was used in the camp - by the guards or members of the Sonderkommando. It was also possible that it was deposited by the Soviet army or any number of other people after the war. During the processing of the finds at Treblinka, a survivor visited the museum and immediately suggested that the pan was proof that the people that were sent to Treblinka believed that they were to be transported "to the east" where they would start new lives. Hence, this offered another possible interpretation - that the pan belonged to someone who ultimately perished in the camp. For the survivor, however, this was not a possible interpretation but rather the only interpretation of this object.

This ambiguity raised a number of complex questions over how/if the pan could be presented in an exhibition about the camp's history and about how to address the fact that the archaeological perspective conflicted with the survivor's perspective. Engaging artists in the Finding Treblinka project presented an opportunity to explore these issues. 'A Pan' was specifically designed to initiate debate about the multiple interpretations possible when encountering evidence and to present the idea that archaeologists should not be afraid to engage in ongoing debate (Figure 5, second from right). It was designed to demonstrate that presenting multiple interpretations and "many truths" can be a more appropriate approach than settling on one truth (McGrattan 2012). The latter is especially true where doubt exists as it may provide further opportunities for those who seek to deny the Holocaust. Instead of being seen as a hindrance, these interpretations should be viewed as providing an insight into conflicting historical narratives, all starting from the same point (the pan) but offering various lineages, some dating back to when the camp was active and operational, and others to more recent events in Polish history. The artwork here offers a viewer experience that does not attempt to direct and instigate a particular response but places visitors to the exhibition at the heart of the project and its processes. The form of the artwork stresses that any particular view is valid and there is no construct used to favour any particular view. Hence, the viewer themselves is encouraged to engage in discussions concerning these interpretations and other possibilities. 
Other objects that could not be dated were also still displayed in the museum at Treblinka, but with an accompanying description that was clear about this ambiguity.

Building on this approach, when curating both exhibitions about Treblinka, the authors were keen to ensure that the processes that led to the discoveries of the items were also explained. Doing this allowed visitors to understand the forensic archaeological process. It demonstrated how conclusions were drawn about individual items and assemblages, the wide range of techniques that now exist to document Holocaust sites, the challenges involved in investigating crimes decades later, why ambiguities exist and the ways in which the methods chosen were adapted to ethical and religious issues surrounding the sites. It was hoped that visitors would be inspired by the scientific techniques used at both camps and that they would understand that, although excavation had an important role to play in the investigation, it was the non-invasive methods that preceded it that facilitated the discovery of the below-ground material remains. This was deemed particularly important for the exhibition at Treblinka, where the objects were so central to the re-telling of Treblinka's history, in order to demonstrate the importance of the wider contextual information that was derived by the macro-level surveys facilitated by these earlier non-invasive approaches.

\subsection{Presence and Absence}

In both our reporting and dissemination of the archaeological work at Treblinka, it has also been important to recognise that the remains found represent only a small sample of materials that were left behind when the camps ceased to function, consistent with many other Holocaust sites. Many items have undoubtedly been looted since the end of the war and many were destroyed by the perpetrators. Therefore, as far as possible, we need to consider what may be missing as much as we consider what is present. Valuable items such as jewellery, which are perhaps the most likely to bear names, and easily dateable items e.g. items exhibiting Nazi insignia, are in many ways the least likely to be found since they would be the first to be looted and/or removed by the perpetrators. Indeed, only one item with identifiable Nazi insignia was found at Treblinka.

Likewise, the excavations undertaken were on a small scale. Whilst they clearly demonstrate the potential for evidence to survive, they also raise many questions; not least of all how much more excavation should be undertaken at the site in order to document its history. The discovery of items has not only inspired a long-term dissemination strategy but also a new phase of archival research. Thus the project's methodology has gone full circle, a trend that will likely continue as this new research and future excavations lead to the need for evolving forms of dissemination.

The authors are also very much aware that, although the exhibition included the history of the labour camp, the artworks focused exclusively on the extermination camp at Treblinka. The contemporary reality is that the labour camp is neglected and therefore archaeological attention has been focused on mapping the site, rather than excavating buried remains. This made it difficult for the artists to respond to the material culture of this site it at this stage. However, this is something we would like to pursue in the future One lesson that the authors have learnt is that Holocaust archaeology requires a long-term commitment.

\section{PROVIDING ACCESS AND IMPACT}

One of the key challenges that we faced in the course of designing the Finding Treblinka exhibition was how to provide access to a broad and geographically diverse audience. This was particularly problematic as the objects themselves had to remain at Treblinka. How can archaeologists present the results of their work without the material culture on which it is 
based? As this paper has hopefully shown, collaborations between artists and archaeologists, the integration of archival material and testimony, and the use of photography and digital resources offer some possible solutions. But how effective were these approaches? At the time of writing, the travelling exhibition has not closed but for the final part of this paper, an initial overview of the reactions to the travelling exhibition are provided. Our main source of analysis are the responses taken from questionnaires given to visitors, interviews and informal comments documented by staff at the Wiener Library.

All responses to questions such as 'what did you think the key message was?' and 'what did you learn from this exhibition?' demonstrated that visitors' understanding of Treblinka had been increased and that this was grounded in the new evidence provided by the archaeological investigations and, in many cases, by the presence of the artworks. Respondents commented that they had learnt more about 'the detailed planning that went into the construction of this place', how 'the Germans tried to cover up their crimes' and 'the camp layout', suggesting that the focus on the material remains within the exhibition was clearly understood and that it resonated with the audience.

Interestingly, although there was a focus on the material culture in almost all responses to general questions about learning, "take home messages" and the importance of the exhibition, when asked about the individual item that they found most interesting, of a sample of twentyfive visitors, there was a bias towards more traditional sources such as documents and testimonies (eleven respondents). However, some visitors did indicate that they found the maps (two respondents), the artworks (four respondents), the tiles from the gas chambers (one respondent) and the hair clips (one respondent) the most interesting. One respondent echoed the sentiment expressed by others that 'that the work continues filling in the gaps of our understanding'. This suggests that the aim of the exhibition - to demonstrate the importance of archaeology and art in furthering our understanding of the crimes at Treblinka - has been achieved. Another respondent stated that the exhibition demonstrates that there are 'still many questions still to ask/answer', whilst others commented on the importance of past and future work in enhancing knowledge. This was also the curators' aim - to present new material whilst engaging with the fact that new material may still be found, and to demonstrate that there may be a need for new and more up to date artistic and archaeological responses in the future.

One visitor did comment that they would have liked to have seen more photographs of objects, whilst three commented that they found it difficult to engage with the artworks, although it was unclear from the responses whether they would have preferred discovered objects instead. Overall, however, the absence of the original objects does not appear to have been an issue and the interdisciplinary approach taken appears to have made their presence felt in other ways.

Comments on the contemporary relevance of the work were also received; one visitor stated that the exhibition demonstrated 'that the Nazis can't escape what they did', whilst others that it showed 'what we as humans are capable of'. One visitor stated that 'archaeology [is] important in uncovering deception in an age of denial'. These responses open up some of the discourses that we hoped the exhibition would invoke. Whilst the deception of the perpetrators was observed through the archaeological evidence, the recognition of how this relates to contemporary debates was experienced via the artworks, as they provoked more critical responses of the world around us (Wistrich 2012; Schofield, 2007).

One of the outcomes that was difficult to access was whether or not the travelling exhibition (where the objects were absent) inspired people to want to visit Treblinka. This issue was part of a continual dialogue between the authors. The need to reveal the relevance of material culture whilst also creating questions was essential, as we did not intend the travelling exhibition to be an alternative to visiting Treblinka, but rather a means of creating curiosity or another personal response so that a new audiences visit the site in person - essential if one is to view the material 
traces first hand, understand what little visual evidence survives above the ground and engage with the memorial landscape.

Perhaps ultimately it is the ability of the archaeological work and exhibitions to affect established narratives concerning Treblinka and educational programmes relating to it which will reveal the extent to which the project achieved its longer-term aims. Early indications are positive, as the work has already featured in teacher-training programmes, school- and university-level training and the international media. However, changing the long-held views concerning Treblinka's history, which have been propagated over the last seventy years, is one which the author's recognise will require a combination of time and continued work.

\section{CONCLUSION}

The application of forensic archaeological methods has clearly demonstrated that a significant amount of physical evidence survives within the landscape of the former extermination camp at Treblinka. Due to the shifting value placed upon objects at sites of atrocity, items that were once seen as unimportant or as unwanted detritus of these horrific crimes, have become essential elements in the telling and re-telling of site's history. Many of the items discovered have illustrated spatial trends, victim experiences and the camp's architecture.

However, given the number of years that have passed since the crimes took place, a number of challenges present themselves when attempting to locate and establish the provenance of such items. Likewise, archaeologists have to find innovative and effective ways of presenting their findings in order to respond to and engage with the public in an ethical and sensitive manner.

As this paper has sought to demonstrate, the Finding Treblinka exhibition project has taken an interdisciplinary approach to finding and exhibiting material culture at Treblinka in order to initiate new debates and provide novel means of communicating to a diverse audience. Archaeology and art have successfully enhanced historical knowledge about the site and about techniques that can shed new light on historic genocide, beyond the familiar tropes of historical enquiry. This way of addressing the factual work done via the archaeological surveys allowed the exhibitions to have a rich dynamic offering both concrete and speculative histories. This was intended to inspire a continual discourse about what Treblinka was and about what forms its landscape and physical evidence take in the present and the future; something which is now even more pressing given recent announcements to alter the management of the site (The Times of Israel 2016). Internally, we have explored ways that approaches and attitudes to material culture is at the core of our practice and how we can use the common ground of archaeology and art to pose new questions about how we operate collectively and within our respected fields.

Whilst this project is one informed by the past, it is one that looks ahead. Archaeological investigations at Holocaust sites and the analysis of the material culture pertaining to them has a key role to play in education and the synergies between art and archaeology can offer new opportunities to forefront forgotten histories, present evidence to inspire dialogue and, perhaps most importantly, explore the reasons why issues relating to genocide and racial hatred continue to be so relevant in the modern world. As we continue to see a waves of intolerance, the rise of nationalism and the ease with which an advanced industrial state might choose to use its might, the glimpses of the past that Holocaust-era material culture provide offer important reminders of where such trends can lead in the future.

\section{ACKNOWLEDGEMENTS}


Thanks are due to the staff of the Museum of Struggle and Martyrdom in Treblinka and The Wiener Library, Kevin Colls, Dean Northfield and the members of the archaeological field teams who have worked at Treblinka as part of the Finding Treblinka project. Thanks are also due to artists Janine Goldsworthy, Hilary Jack, Dave Griffiths and Jenny Steele, who works are included in the Finding Treblinka exhibitions. Financial support for the exhibition project was received from Staffordshire University and other donors who wish to remain anonymous.

This article was made possible thanks to the author's (Caroline Sturdy Colls') tenure as a Fred and Maria Devinki Memorial Fellow at the Jack, Joseph and Morten Mandel Center for Advanced Holocaust Studies, United States Holocaust Memorial Museum.

\section{REFERENCES}

Arad, Y. (1999). Betzec, Sobibor, Treblinka: the Operation Reinhard death camps. Indiana, Indiana University Press.

Bomba, Abraham. RG-60.5011. Film ID: 3197-3205. Visual History Archive. USC Shoah Foundation Institute. Accessed online at the United States Holocaust Memorial Museum on [6 June 2016].

Chrostowski, W. (2004). The extermination camp Treblinka. Herts, Vallentine Mitchell and Co Ltd.

Evans, H. (2014). In their shoes: conservation and display at the United States Holocaust Memorial Museum. In Cornish, P. and Saunders, N. Bodies in Conflict. London, Routledge.

Friedman, Simon. Interview 11175. Visual History Archive, USC Shoah Foundation. 1996. Web. 5 Oct 2012.

International Military Tribunal at Nuremberg. (1947). Testimony of Samuel Rajzman on Treblinka. Volume 8, page 325. Available at http://avalon.law.yale.edu/imt/02-2746.asp\#rajzman1. Accessed 15 January 2007.

Kjedbaek, E. (2009). The Power of the object. In Kjedbaek, E. (ed.) Museums and World War II. Edinburgh, Museumsetc.

Kopówka, E. and Rytel-Andrianik, P. (2011). Dam im imię na wieki: Polacy z okolic Treblinki ratujacy Żydów. Warsaw, Wydawnictwo Sióstr Loretanek.

Krzepicki, A. (1979). 'Eighteen days in Treblinka' in Donat, A. The death camp Treblinka: A documentary. New York, Holocaust Library, pp. 77-146.

LaCapra, D. (1996). Representing the Holocaust: history, memory and trauma. New York, Cornell University Press.

Lennon, J. J. and Foley, M. (2000). Dark tourism. Andover, Cengage Learning EMEA.

Linenthal, E.T. (2001). Preserving memory: The struggle to create America's Holocaust museum. New York, Columbia University Press. 
Łukaszkiewicz, Z. (1948). Oboz pracy w Treblince, Biuletyn GKBZH w Polsce III. OKBZN, Siedlce, pp. s. 109-124.

McGrattan, C. (2012). Memory, politics and identity: haunted by history. Basingstoke, Palgrave Macmillan.

Partee Allar, L. (2013). Holocaust tourism in a post-Holocaust Europe: Anne Frank and Auschwitz. In: White, L. and Frew, E. Dark tourism and place identity: managing and interpreting dark places. London, Routledge.

Potarcari Memorial. (2016). http://www.potocarimc.ba/. Accessed 20 September 2016.

Rajchman, C. (2011). The last Jew of Treblinka. New York, Pegasus Books.

Schofield, J. (2007). Intimate engagements: art, heritage and experience at the 'Place-Ballet' The Internal Journal of Arts in Society 1(5): 105-114.

Schnapp, J., Shanks, M. and Tiews, M. (2004). Archaeology, modernism, modernity: editors' introduction. In Schnapp, J., Shanks, M. and Tiews, M. Archaeologies of the modern, a special issue of Modernism/Modernity. Baltimore: Hopkins University Press, pp. 1-16.

Sereny, G. (1995). Into that darkness: from mercy killing to mass murder. London, Pimlico.

Stone, P. D. (2006). A dark tourism spectrum: Towards a typology of death and macabre related tourist sites, attractions and exhibitions. Tourism: An Interdisciplinary International Journal 54(2): 145-160.

Sturdy Colls, C. (2015a). Holocaust archaeologies: approaches and future directions. New York, Springer.

Sturdy Colls, C. (2015b). 'Uncovering a painful past: archaeology and the Holocaust'. Conservation and Management of Archaeological Sites 17(1) 38-55.

Sturdy Colls, C. (2014). Gone but not forgotten: archaeological approaches to the landscape of the former extermination camp at Treblinka, Poland', Holocaust Studies and Materials 3: 239289.

Sturdy Colls, C. (2012). Holocaust archaeology: archaeological approaches to landscapes of Nazi genocide and persecution. Journal of Conflict Archaeology 7(2): 71-105.

Sturdy Colls, C. and Branthwaite, M. (2016. Treblinka: Archaeological and Artistic Responses. Centre of Archaeology Book Series: Special Issue. USA: Amazon CreateSpace.

Taylor, J. (2014). Concentration camp uniforms as a tool of subjugation. In Cornish, P. and Saunders, N. Bodies in conflict. London, Routledge.

The Times of Israel. (2016). Poland suggests takeover, upgrade of Treblinka museum http://www.timesofisrael.com/liveblog_entry/poland-suggests-takeover-upgrade-of-treblinkamuseum/. Accessed 23 June 2016. 
Webb, C. and Chocholatý, M. (2014). The Treblinka death camp: history, biographies, remembrance. Stuttgart and Hannover, ibidem Press.

Weinstein, E. (2002). Quenched steel: the story of an escape from Treblinka. Israel, Yad Vashem.

Wiernik, J. (1944). A year in Treblinka: an Inmate who escaped tells the day-to-day facts of one year of his torturous experience. New York, American Representation of the General Jewish Workers' Union of Poland.

Willenberg, S. (1989). Surviving Treblinka. Oxford and New York, Wiley-Blackwell.

Wistrich, R.S. (2012) Holocaust denial: the politics of perfidy. Berlin/Boston, DE, De Gruyter.

Ziębińska-Witek, A. (2014). The representation of death in exhibitions: the case of the State Museum at Majdanek. In: Gigliotti, S., Golomb, J. and Steinberg Gould, C. Ethics, art, and representations of the Holocaust. Plymouth, Lexington Books.

\section{FIGURE CAPTION LIST}

Figure 1: The memorial at Treblinka extermination camp in 2013 (Copyright: Centre of Archaeology, Staffordshire University).

Figure 2: A selection of items found during archaeological excavations at Treblinka in 2013 in two trenches in and around the old gas chambers: tiles from the old gas chambers (top), a selection of jewellery, including a rose-shaped brooch, and hair clips (centre), a belt buckle (bottom right), scissors (bottom centre) and a flip knife (bottom right) (Copyright: Centre of Archaeology, Staffordshire University).

Figure 3: A selection of items found during archaeological walkover survey at Treblinka: a pan (top left), nivea tins (top right), a sign bearing the words "Lager Polizei" and a swastika (second row, left), a military water bottle (second row, right), a food dish (third row, left), a metal cup (third row, right), beer bottle tops (bottom left) and a metal cooking pot (bottom right) (Copyright: Centre of Archaeology, Staffordshire University).

Figure 4: The Finding Treblinka permanent exhibition at the Museum of Struggle and Martyrdom in Treblinka in August 2015. (Copyright: Michael Branthwaite).

Figure 5: The artworks commissioned for the Finding Treblinka exhibition as displayed at the Museum of Struggle and Martyrdom in Treblinka in August 2015. From left to right: Dave Griffiths 'Deep Field [Looking Squarely Ahead]'/Janine Goldsworthy 'Rose Brooch'/ Michael Branthwaite 'A Pan' (plinth second from right)/ Hilary Jack 'Treblinka Finds'/ Jenny Steele 'arm c(hair)'. (Copyright: Michael Branthwaite).

Figure 6: The Finding Treblinka exhibition at The Wiener Library in July 2016 (Copyright: Dean Northfield/Staffordshire University). 